\title{
ARTICLES
}

\section{THE CHANGING INTERNATIONAL ORDER AND MONGOLIA'S SECURITY}

\begin{abstract}
K.Bold
Introduction

Since Mongolia launched its policy of "gradual limited reform" in 1988, its efforts to diversify its diplomacy have borne considerable fruit, and the conditions for the country's peaceful environment have improved dramatically. However, recent political developments in both internal and external affairs - such as the approval of a new constitution based on universal principles of political democracy, the transition to a market-oriented economy, the denunciation of socialist dogma and adherence to foreign and domestic policies to meet the national ineterests, the disappearance of Mongolia's only ally, the Soviet Union, and more access to the world community - lead us to ask whether Mongolia should reevaluate its securuty policy to adjust to a new situation in the after-

The changes that may affect Mongolia's security policy are the dissolution of the Soviet Union, Mongolia's improving and expanding relations with China, and its political and economic open-door policy. What effect would these changes have on the security of Mongolia? If any changes have been brought about, how should Mongolia best adjust it to such changes? These and other questions related to recent political developments surrounding Mongolia are worth scrutinizing to see whether any change or adjustment is necessary for maintaining Mongolia's security.
\end{abstract} math of the cold war.

\section{Dissolution of the Soviet Union}

Glasnost and perestroika, initiated by former President M.Gorbachev, eventually led to the collapse of one of the world's greatest military powers and the disintegration of the Soviet Union. There emerged twelve states and the Commonwealth of Independent States, among which the Russian Federation is the largest in terms of size, resources and power.

The Russian Federation consists of twenty republic and eleven autonomous units, including all the territories in the Far Eastern part. It now has pro- 
claimed itself the successor to the Soviet Union and thereby has assumed the latter's in-ternational and internal obligations. Russia remains the only northern neighbor of Mongolia.

Our most immediate concern with Russia is whether it will continue the policies of the Soviet Union which, in turn, raises the question whether Russia will identify its national interests with those pf the Soviet Union. As Russia succeeds to the interests, rights, and obligations of the Soviet Union, it is very likely that it will do so.

It should be noted that Mongolia's greatest importance to the Soviet Union lay in its geopolitical location. Mongolia constituted a shield for the Soviet Union in Northeast Asia. In addition, the Soviet Union's support for Mongolia was ideologically motivated.

The Russian government has stated that it will honor all agreements between the Soviet Union and China, including the Sino-Soviet joint statement of 1989. The political core of this statement is similar to the Sino-Soviet agreement of 1924 and differs only in changed time and conditions. The obligation, which in 1966 had been stipulated under Article 5 of theTreaty of Friendship, Cooperation and Mutual Assistance between the Mongolian People's Republic and the USSR, was concluded under the shadow of Sino-Soviet ideological confrontation, and today it is actually in limbo.

Given the fact that there were never any permanent consulting mechanisms on security matters nor any joint command and combined forces which are based on a legal framework, Mongolia and the Soviet Union were never true security allies.

They were only defense allies within the narrow sense of Sino-Soviet relations. The alliance, which was based on the principle of "friendship and allround cooperation with the Soviet Union as Mongolia's only security guarantee." has declined to peaceful coexistence. Defense cooperation between the two countries was suspended except for ongoing technical talks to complete the Russian withdrawal.

It is normal behavior in inter-state relations that the security policy of a great power toward its neighbor is based on peaceful coexistence. If one supposes that Russia's security interests are identical to those of the Soviet Union, such a supposition could be based on geopolitical and economic interests between the two, which have been and will continue to remain the same in the future.

Russia's current military impotence and economic troubles will undoubtedly encourage it to move closer to Chirm. Such a policy, in turn, would have a 
favorable impact on the peaceful environment of Mongolia. Nevertheless, Russia's security interests in Mongolia should also continue to be identified in the context of Sino-Russian relations in the long-term future. Furthermore, it is possible, if not immediately likely, that this interest could be identified beyond those relations.

Meanwhile, it appears that Russia will continue to maintain its current relations with Mongolia not necessarily at the risk of alienating Mongolia but to maintain a balance of interests to Russia's advantage. In light of this, there is a need for frequent consultations concerning security issues between Mongolia and Russia based on new ideas and interests.

\section{The China Factor}

The changes taking place in Sino-Mongolian relations have not come internally but as a byproduct of both global political transformation and regional strategic changes. It is vitally important to understand the logic of the Sino-Mongolian rapprochement and to scrutinize the ups and downs of this process. Improving Sino-Soviet relations since the middle of the 1980s have had implications for Sino-Mongolian relations. Previously, Mongolia was not in a position to unilaterally deviate from the Soviet alliance. But deviation became inevitable as a result of the full normalization of Sino-Soviet relations. True neutrality, however, will be most difficult for Mongolia to achieve, situated as it is between Russia and China. Mongolia has always been willing to accept help from either neighboring nation if that would benefit its national interest.

Sino-Mongolian relations are now entering a new phase, and both countries will have new opportunities to build better relations, casting off all the barriers which had their basis in Sino-Soviet confrontation. The close connection between Sino-Russian and Sino-Mongolian relations will remain a part of the new international order in Northeast Asia, but it is becoming clear that the ability of Sino-Russian relations to alter Mongolia's relations with China is diminishing. This is in the best interests of Mongolia and China.

The normalization and gradual expansion of Sino-Mongolian relations have important foreign policy implications for Mongolia and have opened new opportunities for its security policy that would have been impossible to imagine only a few years ago. Since the signing of the agreement on the complete withdrawal of Soviet troops from Mongolia, Sino-Mongolian defense exchanges have been increasing. Relations with China have also grown stronger primarily as a result of economic considerations Although China is preoccupied with 
domestic economic problems, its assistance to Mongolia has gradually increased as a result of the new relationship between the countries.

China's present and future economic involvement in Mongolia has two implications for bilateral relations; first, China's economic involvement will greatly increase and, second, such economic involvement will strengthen other forms of Chinese interest in Mongolia. Because these two trends may eventually collide and contradict each other, we should pursue policies which will accommodate both trends and thus avoid future collisions.

Historically, Mongolia has viewed both neighbors' policies on many political-strategic issues with caution and even apprehension. Today, historical lessons should certainly be taken into account, but we should not allow ourselves to be trapped by history as we formulate our national security policy.

\section{Mongolia's Security in the Changing International Order}

Since the end of the cold war, there have been new developments in Northeast Asia, but it is still too early to know precisely their implications for an emerging international order. The many factors determining the strategic environment of Northeast Asia are characterized by two phenomena. On one hand, some cold war conditions have continued. They include a lack of progress in arms reductions, a Korean peninsula still caught between cold war confrontation and post-cold war uncertainties, and the Russo-Japanese dispute over the so-called Northern Territories issue. On the other hand, tensions among the key actors have been lowered. These cross-cutting trends very much complicate effective security policies at both national and multilateral levels.

The Gulf War demonstrated that the bipolar world, which came into being in 1945, has ended. The end of bipolarity has not, however, ushered in an era of full multipolarity. Even though the nations of Northeast Asia were not directly involved in the U.S.-led international coalition that defeated aggression against Kuwait, they have nonetheless been affected, and their security requires that they be clear on the Gulf War's implications.

Mongolia has drawn its own lessons from the Gulf War. Given Mongolia's weakness, it could, theoretically at least, easily become another Kuwait. Mongolia has also entertained the idea that the international community, supported by great powers, could transform the United Nations into an effective peace-keeping organization in regional conflicts.

As a result of the reduction of global tensions, the world seems to be moving to a new order where the primary sources of conflict are no longer global 
military threats, but ethnic, religious and territorial disputes. Although no new world order is likely to emerge any time soon, the need for one is here now. Given such an environment, none of the political actors in Northeast Asia has yet revealed what kind of foreign policy it is prepared to follow in its search of a system of security that would be conducive to the area.

Clearly the new post-cold war international order is intended to be global and its principles universal. However, if the New World order is Eurocentric, based upon Western values, and uses relationships between one of the great powers and its allies only, it will be too narrow to succeed politically and would be particularly unsuited for Northeast Asia. Quite briefly, the following features could be applied to the emerging international order:

a. Increasing interdependence of economies, resources, environments and technologies,

b. Diminished importance or breakdown of existing alliances and higher priorities given to general non-alignment and multilateral cooperation

c. Increased importance of regional balances of power

d. Use of military power becoming impractical and meaningless; and

e. Increased importance of the combination of reliance of international cooperation and self-defense.

In a new international order, Mongolia's strategy will not be the same as in the past when it was under the Soviet umbrella. Rather, it may call for Mongolia to assume its own defense burden under an emerging "restricted non-alliance policy."

Given its unfavorable geographical position and heavy dependence on fueling sources of arms, Mongolia should seek a combination of political and military policy, perhaps putting more emphasis on diplomacy in security policy. After two years of heated debate, it can be said that people in Mongolian defense circles generally accept this idea.

Although the choices available to Mongolia in international relations are limited due to its landlocked situation, its new role will be affected by its opendoor policy which will enable Mongolia to join multilateral cooperation in North-east Asia. The establishment in Mongolia of its own channels to the outside world in the emerging multiplier structure diminishes somewhat the country's heavy reliance on its two neighbors. With deterrent conditions thereby provided, Mongolia can more safely expand its efforts to extend contacts far 
beyond Inner Asia. Consequently. Mongolia should focus more efforts on diplomatic solutions to ensure its security.

As Mongolia's policy of national security would be dominated by political considerations, Mongolia should pursue a national defense policy which is based on the concept of "flexible defense diplomacy" under which Mongolia would develop a military doctrine that aims at an ability to protect at least some important places of its territory in case of an emergency until the world community comes to Mongolia's assistance. It is more likely, therefore, that Mongolia will emphasize international efforts to develop sufficient and effective mechanisms of quick

Decision-making in the world community which is important Ro the survival of small countries. That is why Mongolia supports the United Nations' increasing role in crisis resolution.

When formulating a security policy tailored to a new international order and with the changing policy of political and military commitments of Mongolia toward its neighbors, Mongolia should be ready to meet new challenges arising from the nation's changing security requirements both internally and externally. 